\section{Day labor, informality and vulnerability in South Africa and the United States}

\section{Day labor, informality and vulnerability}

\author{
Nik Theodore
}

Department of Urban Planning and Policy, University of Illinois at Chicago, Chicago, Illinois, USA

Derick Blaauw

Department of Economics and Econometrics, University of Johannesburg, Johannesburg, South Africa

Catherina Schenck

Department of Social Work,

University of the Western Cape, Cape Town, South Africa

Abel Valenzuela Jr

Department of Chicano/a Studies,

University of California, Los Angeles, California, USA

Christie Schoeman

Department of Economics and Econometrics,

University of Johannesburg, Johannesburg, South Africa, and

Edwin Meléndez

Department of Urban Affairs and Planning, Hunter College, New York, New York, USA
807

Received 30 January 2014

Revised 28 August 2014 Accepted 20 September 2014

\footnotetext{
Abstract

Purpose - The purpose of this paper is to compare conditions in informal day-labor markets in South Africa and the USA to better understand the nature of worker vulnerabilities in this market, as well as the economic conditions that have contributed to the growth of day labor. The conclusion considers interventions that are underway in the two countries to improve conditions in day-labor markets.

Design/methodology/approach - The paper is based on national surveys of day laborers in South Africa and the USA. A random sample of day laborers seeking work at informal hiring sites was undertaken in each country. The paper presents key findings, compares conditions in South Africa and the USA, and analyzes the relationship between economic change, labor-market dynamics, and worker vulnerability.

Findings - Day-labor work is characterized by low pay, hazardous conditions on the job, and tremendous income insecurity. The day-labor markets in South Africa and the USA perform somewhat different functions within regional economies. Within South Africa, day labor can be regarded as a survival strategy. The growth of day labor in South Africa over the past decade is a manifestation of a formal labor market that is incapable of absorbing the structurally unemployed. Here, day labor is the employment of last resort, allowing workers to subsist on the fringes of the mainstream economy, but offering few pathways into the formal sector. In the USA, the day labor workforce is a largely undocumented-immigrant workforce. Workers seek work at informal hiring sites, maintaining a tenuous hold on jobs in the construction industry. There is evidence of some mobility into more stable and better paying employment.

Practical implications - This paper documents the need for policies and programs to increase employment opportunities for day laborers and to better enforce labor standards in the informal economy.
} 
IJM

36,6

808

Originality/value - This paper summarizes findings from the only two national surveys of day laborers that have been conducted, and it compares for the first time the dynamic within growing day-labor markets in a developed- and emerging-market context.

Keywords Migrant workers, Underemployment, Contingent work, Day labour, Informal economy, Urban informality, Worker centres

Paper type Research paper

\section{Introduction}

Recent academic and popular literature has documented the re-emergence of day labor in a diverse group of countries in Africa, Asia, Europe, and North America. Day laborers gather at informal hiring sites located in public spaces to search for construction, landscaping, and other manual labor jobs. Employment rates tend to be low, as are the wages, and day laborers must contend with heightened levels of employment insecurity. Workplace injuries are common, contributing to the physical and material hardships faced by these workers. Though commonly regarded as an anachronistic employment relation, one that gradually would be eliminated with the "modernization" of an economy, the re-emergence of day labor in both advanced and emerging economies calls into question many of the prevailing interpretations of the persistence and growth of informalized occupations. It suggests that the relationship between this mode of causualized employment and wider patterns of labor market restructuring must be reconceptualized, and it highlights the need for research to document and analyze the vulnerabilities workers face in the informal economy.

The economic conditions that give rise to day labor are numerous and varied (Blaauw, 2010; Doussard, 2013; Peck and Theodore, 2012; Theodore et al., 2006; Williams, 2010). They include, on the demand side, firms' reduced dependence on internal labor markets to organize workforce systems, which in part has been achieved through an increasing reliance both on casualized employment arrangements to fill low-wage occupations and on the employment of temporary workers as a means of achieving greater labor market flexibility and labor cost-savings. On the supply side, these conditions include large-scale worker dislocation from sectors of the economy that previously provided ample employment opportunities, leading to crowding in low-wage labor markets, along with processes of labor market segmentation that constrain unemployed workers' entry into stable, well-paying jobs. They also include breakdowns in systems of human-capital acquisition that result in large numbers of workers who do not possess even the most minimal job-market credentials. Faced with inadequate employment opportunities, many workers turn to day-labor markets as their employment of last resort. Within regional economies, these conditions are exacerbated by uneven geographical development, which creates sometimes vast spatial asymmetries in the demand for labor. And within the sphere of government enforcement of labor standards, the terms under which workers enter employment is further shaped by the reach and extent of regulatory enforcement.

Day laborers encounter a highly unstable job market that provides low and uncertain wages, and few prospects for continuing employment. As a result, like so many workers in the informal economy, day laborers, and their dependents, tend to live in poverty (Blaauw et al., 2006; Valenzuela et al., 2006). In an effort to better understand the vulnerabilities associated with working in day-labor markets, this paper analyzes day-labor work in the USA and South Africa in order to compare the dynamics within day-labor markets in each country. Drawing on the results of national surveys in these two countries which, to our knowledge, are the only national studies that have been 
undertaken to date anywhere in the world, this paper seeks to compare and analyze the prevailing dynamics of day labor in a highly developed and an emerging market economy. We seek to analyze the commonalities and differences in the functioning of day-labor markets in these two contexts to assess the role day labor plays in wider processes of economic restructuring and to evaluate the extent to which this segment of the informal economy provides pathways for workers into more stable employment. The USA and South Africa provide an appropriate point of departure to answer these questions given the growth that has occurred in day-labor markets over the past two decades. The paper analyzes data on day laborers' demographics, employment histories, and earnings to compare and contrast the prevailing economic rationales for the existence of this form of casualized employment while also considering the different socioeconomic circumstances that are prevalent in each country. The paper concludes with a discussion of strategies to improve the labor-market outcomes of day laborers.

\section{Methodology}

This paper draws on the results of two national surveys of day laborers conducted in the mid-2000s. These surveys offer a unique opportunity to analyze commonalities and differences in prevailing modes of informality in two quite different contexts. By analyzing day-labor markets across these two studies, we are able to explore the underlying conditions that support the growth of day-labor markets using a comparative frame of analysis that highlights key differences in the demographics, working conditions, and employment histories of day laborers.

In the USA, the National Day Laborer Survey was administered by the University of California, Los Angeles in collaboration with the University of Illinois at Chicago, New School University, and the National Day Laborers Organizing Network. The survey reached a random sample of 2,660 day laborers at 264 hiring sites in 20 states and the District of Columbia (for a detailed discussion of the methodology used, see Valenzuela et al., 2006). The results of this study are compared to a survey conducted in South Africa using a similar methodology. Day laborers were interviewed across South Africa by the University of Johannesburg and the University of South Africa, following a lengthy process of identifying hiring sites. The size of the population was determined through a countrywide reconnaissance process, during which a census of the number of day laborers was undertaken. The size of the workforce was determined to be approximately 45,000 (see Blaauw, 2010, for a detailed discussion of the research methodology that was followed). The survey reached 3,830 day laborers, representing 8.5 percent of the target population.

Both surveys were administered in-person to job seekers who where present at day-laborer hiring sites. The survey instruments included questions regarding worker demographics, employment patterns, wages and earnings, and material hardships. The completion of these two large-scale, national surveys provides a unique opportunity to compare the dynamics of this informal labor market in a developed and developing country context.

\section{Day laborer demographics}

Based on the data collected in the day laborer surveys, it was estimated that on any given day in the USA, approximately 117,600 workers are either looking for day-labor jobs or are employed as day laborers, whereas in South Africa, at least 45,000 day laborers congregate at more than 1,000 informal hiring sites. This section presents a demographic portrait of day laborers in the two countries, identifying similarities and

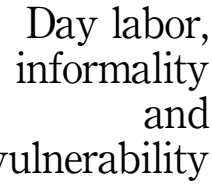

809 
IJM

36,6

810

exploring several distinct differences in the workforces' characteristics and its insertion into the economy.

In both the USA and South Africa, the day labor workforce is overwhelmingly male (98 and 96 percent, respectively) and relatively young. In the USA, day laborers' median age is 34 years old, while in South Africa, nearly 70 percent of the respondents are less than 35 years old. In terms of South African legislation, the term "youth" includes people between the ages of 15 and 34. The vast majority of day laborers can therefore be classified as young, day labor being one manifestation of the persistent unemployment and under-employment among young workers in South Africa (Vakalisa, 2005, p. 53).

Likewise, in both South Africa and the USA, the educational attainment levels of day laborers are low. In South Africa, 6 percent of day laborers never attended school, 20 percent only completed some primary schooling, and just 15 percent had completed secondary schooling. This indicates that eight in ten day laborers have not completed formal schooling, severely limiting their opportunities in an economy that is increasingly capital and technology intensive (Loots, 1998). In the USA, 6 percent of day laborers do not have any formal schooling, 22 percent have five years or less of schooling, 30 percent have six to eight years of schooling, and 42 percent have nine or more years of schooling.

Perhaps the most striking difference between the day laborer workforces in the USA and South Africa is their composition in terms of race and nationality. In South Africa, it is principally South African-born black and colored members of the population who participate in the day-labor market. Slightly more than 92 percent of respondents are black, 7.3 percent are colored, and the remaining one-half a percent consists of whites and Indians. This reflects the overall racial composition of the broader informal sector within South Africa (Saunders, 2005). Although the number of immigrant day laborers in South Africa has been increasing, the vast majority is still South African born. Of the 3,830 survey respondents, nearly 85 percent were born in South Africa, 10 percent were born in Zimbabwe, 3 percent were born in Mozambique, and 1 percent was born in Lesotho.

The situation in the USA is quite different, where US-born workers comprise just 7 percent of the day laborer workforce. Day laborers in the USA are overwhelmingly immigrant and Latino. The majority of day laborers were born in Mexico (59 percent), while a sizable minority (28 percent) are migrants from Central America, and a smaller share (4 percent) are migrants from various South American countries. Furthermore, from the survey, it is estimated that 75 percent of day laborers in the USA are undocumented immigrants, a status that confers distinct disadvantages in terms job opportunities, wages, and working conditions, as well as on the ability of workers to contest violations of labor standards (Fussell, 2011; Gentsch and Massey, 2011; Hudson, 2007).

Differences in the national origin of day laborers in the USA and South Africa raise important questions about the dynamics within the day-labor markets of these countries, as well as questions about differences in the vulnerabilities faced by these workforces. For most day laborers in the USA, this labor market fulfills one of three roles. First, for workers in areas with inadequate employment prospects, due the changing structure of employer demand or because of a cyclical downturn in the regional economy, day labor provides an opportunity for workers to regain a foothold in the job market while also providing an immediate source of earnings. Workers displaced from other sectors of the economy as a result of layoffs and business closings may turn to day labor as a means of labor-market re-entry. Second, for newly arrived migrant workers with limited knowledge 
about job openings or with underdeveloped job-search networks, day labor might be a first job in the USA and an opportunity to acquire work experience, employer contacts, and skills. The residential construction industry in the USA, Iskander and Lowe (2010, 2013) have shown, has been a site of collective skills-building among Latino immigrants, providing workers the opportunity both to transfer building techniques from their countries of origin to the USA and to develop hybrid building methods by applying these techniques to US construction processes and materials. Skills building in this way, they argue, is especially important for immigrant workers with low levels of educational attainment. And third, for workers who are seeking long-term employment in the residential construction industry, day labor, paradoxically perhaps, provides an avenue for securing ongoing work in the industry. The residential construction industry in the USA is characterized by a high degree of casualization and informality, owing to the low levels of unionization in this segment of the industry as well as the prevalence of small enterprises that secure market share by holding down labor costs in this price-competitive industry (Doussard, 2013; Erlich and Grabelsky, 2006). Workers often move between employers as labor demand fluctuates, and employers increasingly are revamping their workforce systems to reduce labor costs by capitalizing on the availability of workers who can be hired on a temporary basis. As a result of these and other factors, many workers have come to rely on day-labor hiring sites as a source of employment.

The job market facing day laborers in South Africa differs from that of the USA in several important respects. Structural deficits within South Africa's "mainstream" economy render it unable to readily absorb new labor-market entrants into formal employment. There simply are not enough jobs to absorb the unemployed population, and many job seekers are compelled to search for work in the informal sector (Bhorat et al., 2001; Muller, 2003). Labor surpluses exist throughout the country, as is reflected in high rates of long-term unemployment and entrenched poverty (Bhorat, 2004; Banerjee et al., 2007; Schoeman et al., 2010). For young job seekers with little or no work experience, their employment prospects are especially bleak (Barrar, 2010; Centre for Development and Enterprise, 2012). Supply-side problems of low educational attainment compound the problem of jobs deficits, especially among older workers who were denied adequate schooling during the apartheid era, and younger workers today who must leave school in order to join the labor force and contribute to family earnings. As a result, day-labor markets in South Africa largely function as a "catchment area" for workers who have lost their formal employment, or who have never had the opportunity to hold a steady job, and for whom the prospects of entry or re-entry into the formal sector are sharply circumscribed.

\section{Employment dynamics in day-labor markets}

Day laborers in the USA and South Africa perform a wide range of manual-labor tasks, most related to the construction and landscaping industries (Table I). The most commonly held jobs are physically demanding, and several are associated with heightened risks to worker health and safety.

Determining the extent to which day laborers have held full-time employment can provide valuable insights into the stocks and flows within this informal labor market. In the USA, 57 percent of day laborers have held a regular, permanent job in the country, most commonly in construction, restaurant work, or manufacturing, and 90 percent held employment in their country of origin, often in the agricultural sector, prior to immigrating to the USA. Likewise, in South Africa, 50 percent of day laborers surveyed had previously held a formal-sector job.

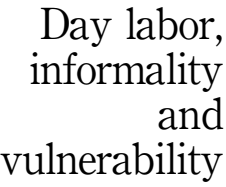

811 
IJM

36,6

812

One of the key differences in the dynamics of day-labor work between the two countries is the length of time in which day laborers are involved in this informal-sector activity (Schenck and Blaauw, 2008). Nearly three quarters (74 percent) of day laborers in the USA have worked as a day laborer for three years or less, and 44 percent percent have been a day laborer for less than one year. The presence of short spells as a day laborer (say for one year or less) suggests that a substantial share of workers are able to make the transition out of the day-labor market, presumably to better-paying, more stable employment. What is not clear, however, is whether these transitions are enduring or whether day laborers simply cycle in and out of more stable employment, returning to informal hiring sites following job loss. These figures also suggest that the day-labor market performs something of a shock-absorber function for the US economy, receiving workers who have been displaced from other sectors during economic downturns.

In South Africa, day laborers, on average, have been engaged in this activity for far longer, with many working as a day laborer for their entire adult life. Less than half (48 percent) of day laborers in South Africa worked as a day laborer for three years or less, and under 15 percent had worked as a day laborer for less than one year (Figure 1). These findings lend credence to the conclusion that employment in the informal economy in South Africa is often long term in nature (McKeever, 2007).

To further explore the employment trajectories of day laborers in South Africa, an adjusted stock-flow model is utilized to illustrate the entry into the sector (Figure 2). Within the day-labor market, 50.2 percent of workers last held a job in the formal sector, while 46.4 percent had not previously held any type of employment (3.4 percent did not answer the question in the survey). For those exiting the formal sector, layoffs accounted for the overwhelming majority of those exits.

These statistics underscore a key difference between South African day laborers and their counterparts in the USA. For many day laborers in the USA, even some of those who are undocumented immigrants, securing work through informal hiring sites can lead to their eventual integration into the formal economy. For most South African day laborers, on the other hand, the combination of demonstrably inadequate labor demand and their low-levels of educational attainment likely relegates these workers to the informal sector for the long term. Working as a day laborer in South Africa has therefore become a means of survival, casting doubt on the premise that the informal economy functions as a stepping stone to employment in the formal economy (McKeever, 2007). Arguably, there is a danger that it may in fact reinforce income inequalities that already exist in the wider economy (Banerjee et al., 2007).

Table I.

Top six occupations of day laborers in the USA and South Africa, and percentage reporting that they have held a given job

\begin{tabular}{llll}
\hline \multicolumn{1}{c}{ USA } & & & South Africa \\
Occupation & $\%$ & Occupation & $\%$ \\
\hline Construction laborer & 90 & Gardening & 65 \\
Mover & 83 & Loading and unloading & 53 \\
Gardener/landscaper & 83 & Digging/shoveling & 33 \\
Painter & 80 & Construction & 33 \\
Roofer & 66 & Bricklaying assistant & 32 \\
House cleaner & 64 & Painter assistant &
\end{tabular}

Source: Survey data 

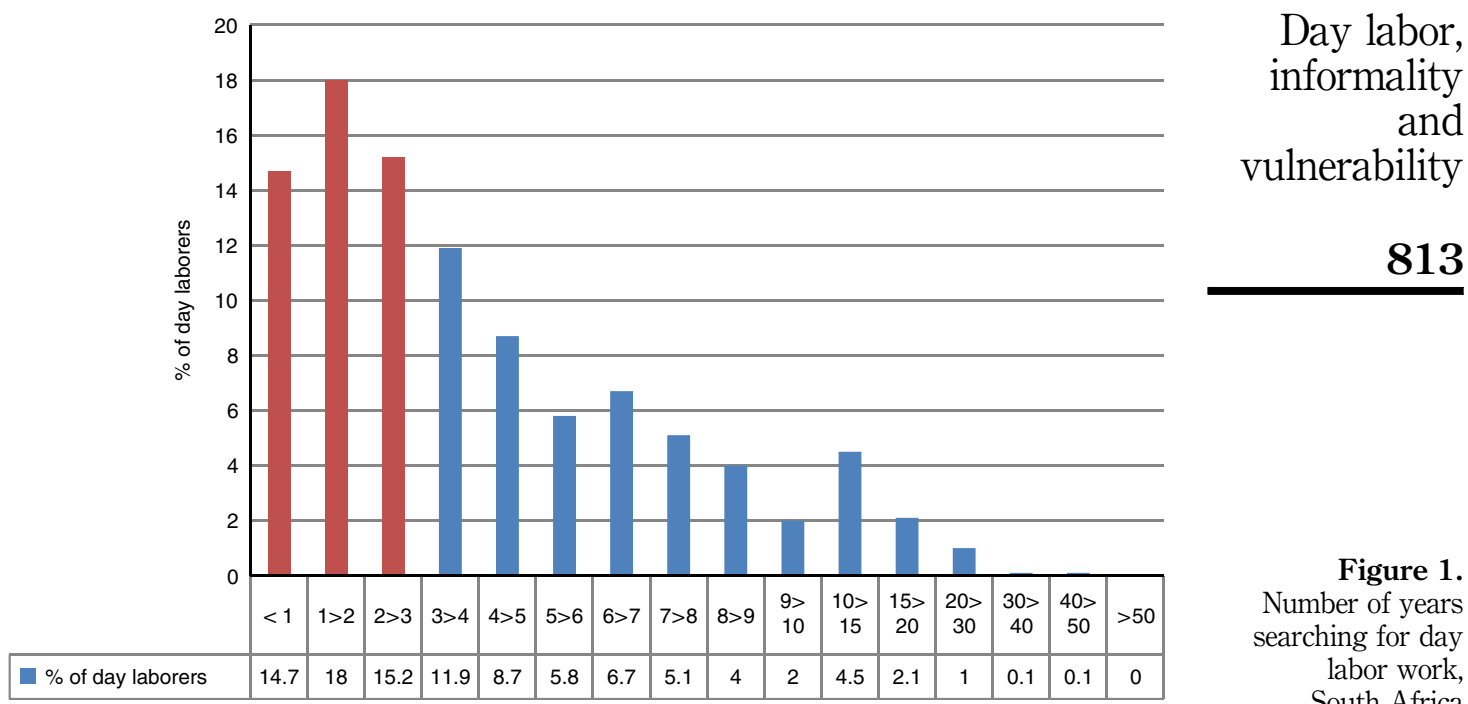

Source: Survey data

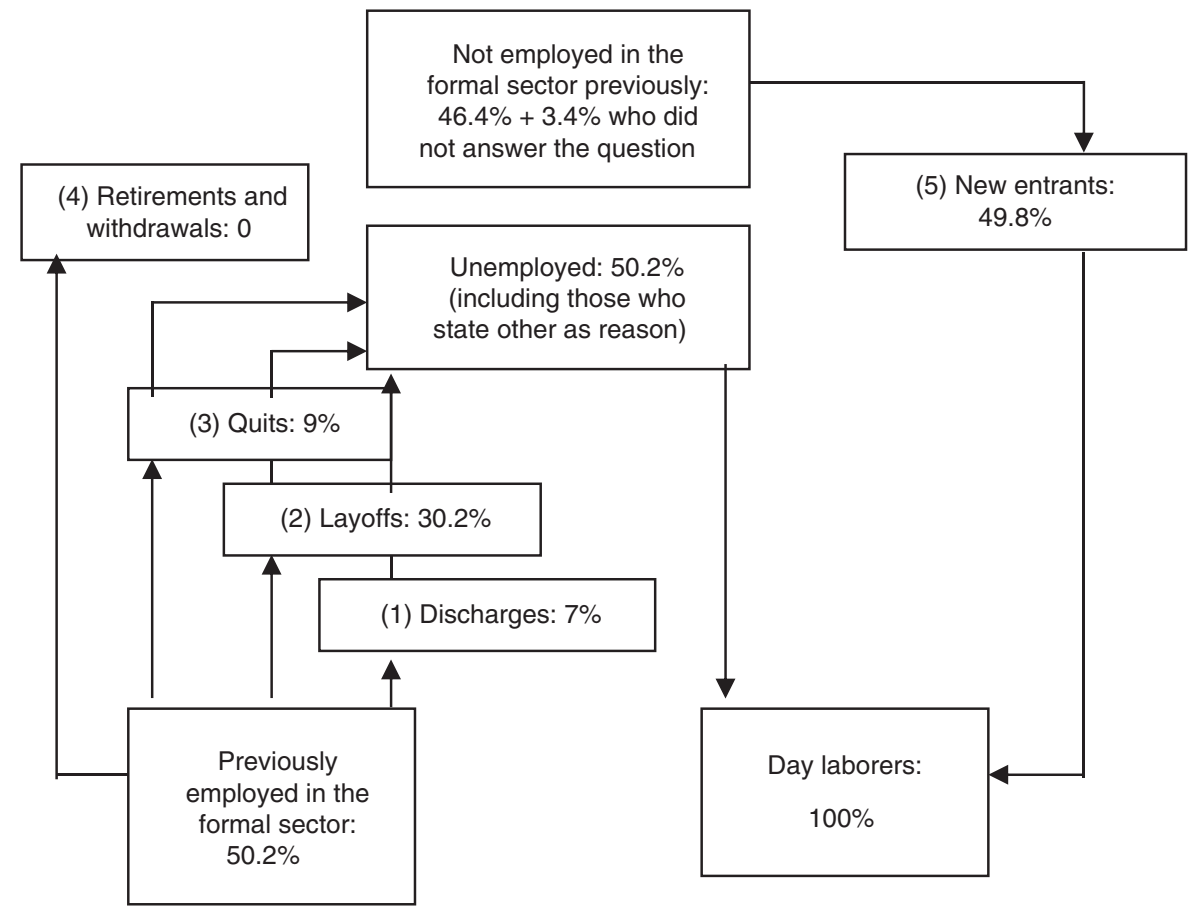

Source: Adapted from McConnell et al. (2009); survey data

Figure 2.

The adjusted stock-flow model of day laborers, South Africa 
IJM

36,6

814

In contrast to what we have characterized as the day-labor market's shock-absorber function in the USA, South Africa's day-labor market appears to perform a different role within regional economies, operating as a reservoir of underemployed workers. With high levels of unemployment, especially in cities, day-labor markets have become overwhelmed and they are unable to provide sufficient employment opportunities or earnings. Data from South Africa suggest a clear relationship between macroeconomic conditions and the size of the day-labor workforce. As shown in Figure 3, since the early 1980s, the growth in the day-laborer workforce has paralleled a rise in the national unemployment rate, a pattern that seems to have become further entrenched in the late 1990s and early 2000s.

The graphical representation in Figure 3 suggests a two- to three-year lagged correlation between the national unemployment rate and the year that day laborers in South Africa turn to this informal economic activity. This apparent relationship is further analyzed by way of a standard correlation analysis. The increase in the number of job seekers becoming day laborers is positively correlated (at the 0.05 level of confidence, with a $t$-statistic of 5.49 and a critical $t$-value of 3.707) with the unemployment rate in South Africa. The correlation coefficient between the year that a worker started as a day laborer and the unemployment rate at the time is 0.73 . When the year that day laborers in South Africa resorted to this activity is correlated with the unemployment rate of two years earlier, the correlation coefficient is 0.84 and no less statistically significant. The $t$-statistic increases to 7.58 , with a critical $t$-value of 3.745 at the 0.05 level of confidence. This lagged correlation supports the contention that day labor tends to be the employment of last resort for people who either are unemployed or who have never been employed. Day labor is a way to minimize the costs of jobseeking in the context of entrenched structural unemployment among less-educated

Figure 3.

The year in which workers began day laboring and the unemployment rate, South Africa

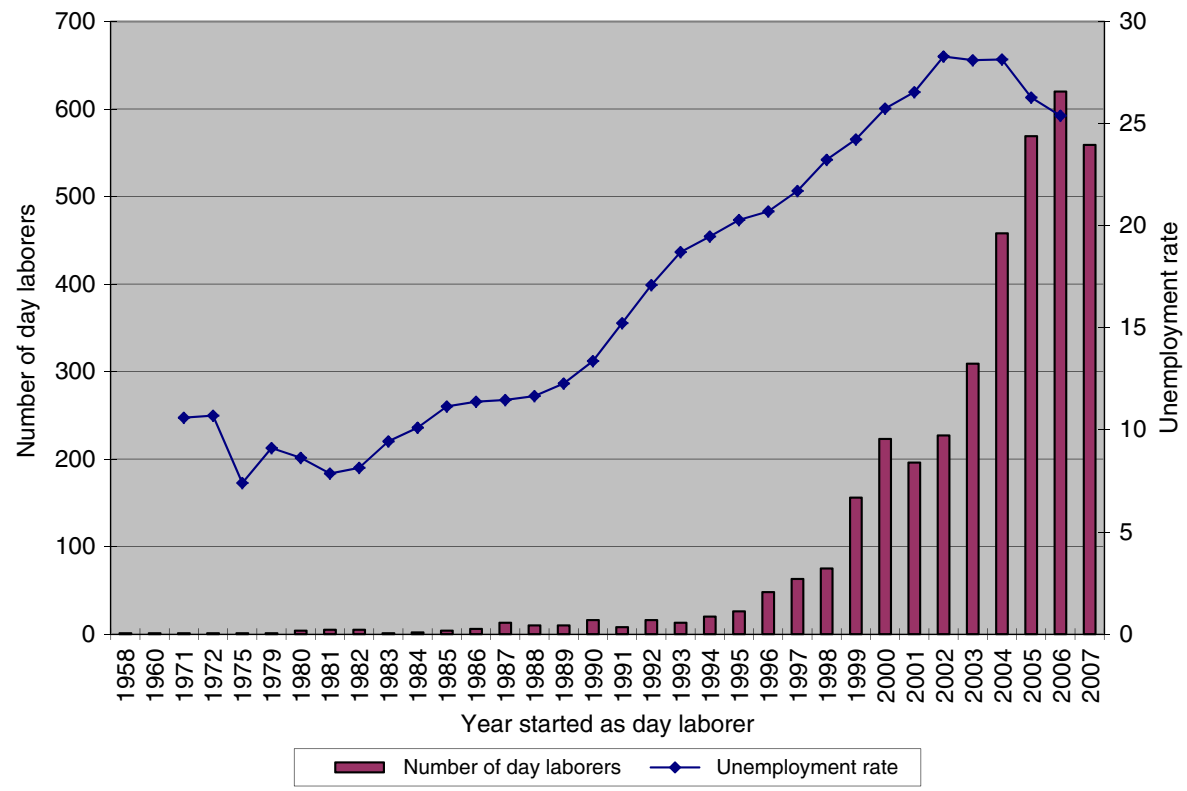

Source: Survey data; Quantec (2007) 
workers, as well as the economic burdens faced when a formal sector job is lost or difficult to obtain in the first instance (Loots, 1998; Barker, 2007).

These indicators, combined with information gathered from worker interviews, suggest that as a number of South African industries have restructured and retrenched, low-skilled workers have been displaced in large numbers, leading to crowding at informal hiring sites. The sustained high unemployment rates that have beset South Africa are an indication of enduring jobs deficits throughout the country. It is considerably more difficult for day laborers, and for low-skilled workers in general, to obtain alternative employment in the formal sector when unemployment rates persist at such extraordinarily high levels (Schoeman et al., 2010; Schoeman and Blaauw, 2009).

\section{Day laborer earnings and vulnerabilities}

Day laborers' earnings are characterized by chronic instability and insecurity. Workers are hired strictly on an as-needed basis, the employment "contract" is verbal and unsecured, and basic employment conditions, such as the tasks involved, the wage, and the length of employment, are usually discussed and negotiated in a matter of moments. Day laborer earnings in the USA vary seasonally, as well, leading to considerable earnings volatility over the course of a year. Figure 4 compares typical wages during a "good" month when work is plentiful and a "bad" month when it is scarce. It shows that the median earnings level in a good month is $\$ 1,400$, while in a bad month it falls to just 36 percent of peak-period levels, or $\$ 500$. Therefore, even in cases where day laborers have many more good months than bad months, it is unlikely that their annual earnings will exceed $\$ 15,000$, keeping most workers in this job market at or below the federal poverty threshold.

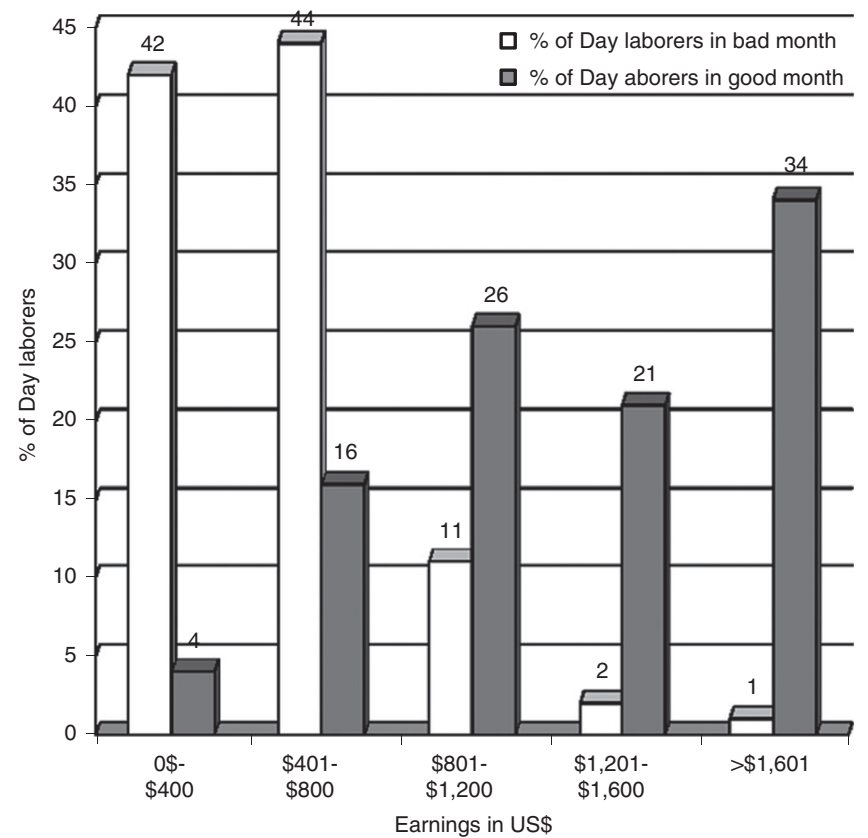

Source: Survey data
Day labor, informality and

vulnerability

815
Figure 4.

Earnings of day laborers in the USA for a "good" month and a "bad" month 
IJM 36,6

816

Day laborers in South Africa are faced with similar challenges regarding earnings instability and insecurity. They must confront unfulfilled expectations in terms of their reservation wages and they must contend with persistently low daily earnings. The variance in the daily and weekly wages highlights the uncertainty experienced by day laborers in terms of their income (Figures 5 and 6). Earningslevels are exceedingly low, even for workers who are able to secure employment in a "good" week.

The observed variances in day laborers' earnings, both the USA and South Africa, reflect workers' daily struggle to hedge against the risks of unemployment that are endemic to day-labor markets. Any unfavorable event, such as an injury or illness, a reduction in employer demand, or even a spell of inclement weather, will immediately reduce their earnings. As the data from the two national surveys have shown, day laborers can ill afford these income losses. Moreover, low earnings, and the fact that the prospects for future earnings are largely unknown, point to the fundamentally social nature of the market mechanism that ostensibly governs informal hiring sites (see Peck, 1996). Day laborers must contend with very real survivalist considerations, and the daily search for work in crowded labor markets creates a downward drag on wages and working conditions. These downward pressures affect day laborers, almost irrespective of their human-capital attributes; all day laborers must compete for work in a market where the balance of power is tilted decisively in the direction of employers. The labor surpluses present at informal hiring sites allow employers to act as price-setters, and they will continue to search for workers until their desired wage rate is met. Moreover, because it is difficult for day laborers to certify their skills in ways that are legible to employers, more-skilled day laborers are often unable to distinguish themselves from less-skilled workers, impeding the use of skills differentiation as a means of commanding higher wages. As a result, the threat of wage undercutting by fellow day laborers means that, barring efforts to collectively bargain wages at informal hiring sites, workers will have enormous difficulties in independently raising wage rates. And although there is some evidence that better educated day laborers in South Africa command higher wages and set higher reservation wages, when compared to measures of worker economic security, these differences are modest,

Figure 5.

The lowest vs highest daily wage earned by day laborers in South Africa during the 12 months prior to being surveyed

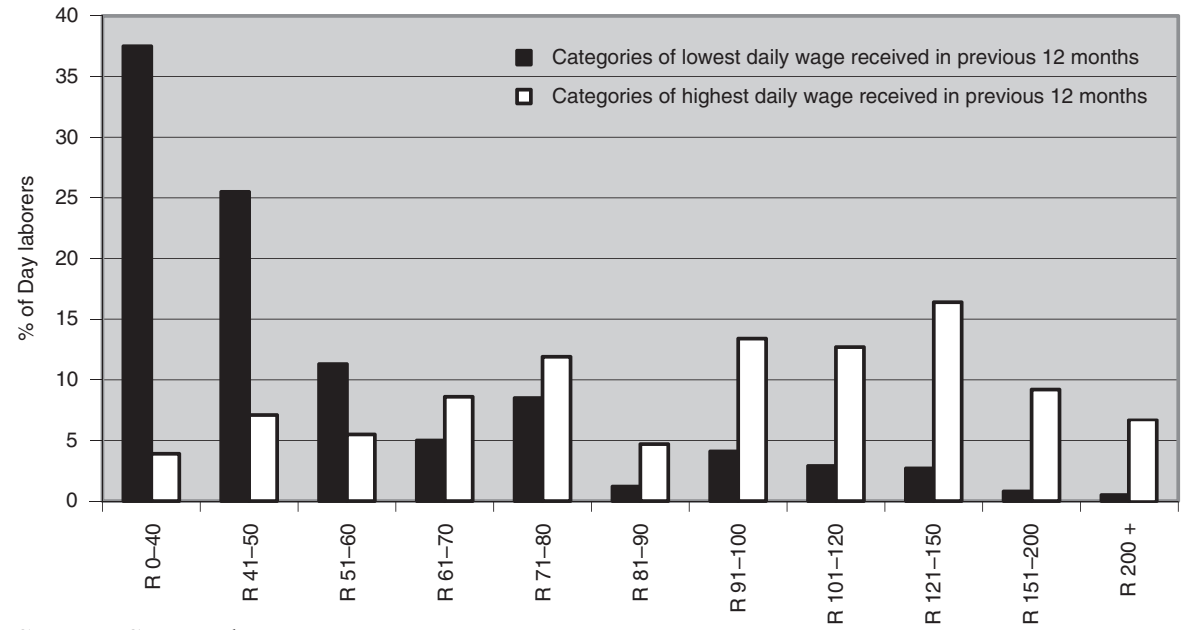

Source: Survey data 


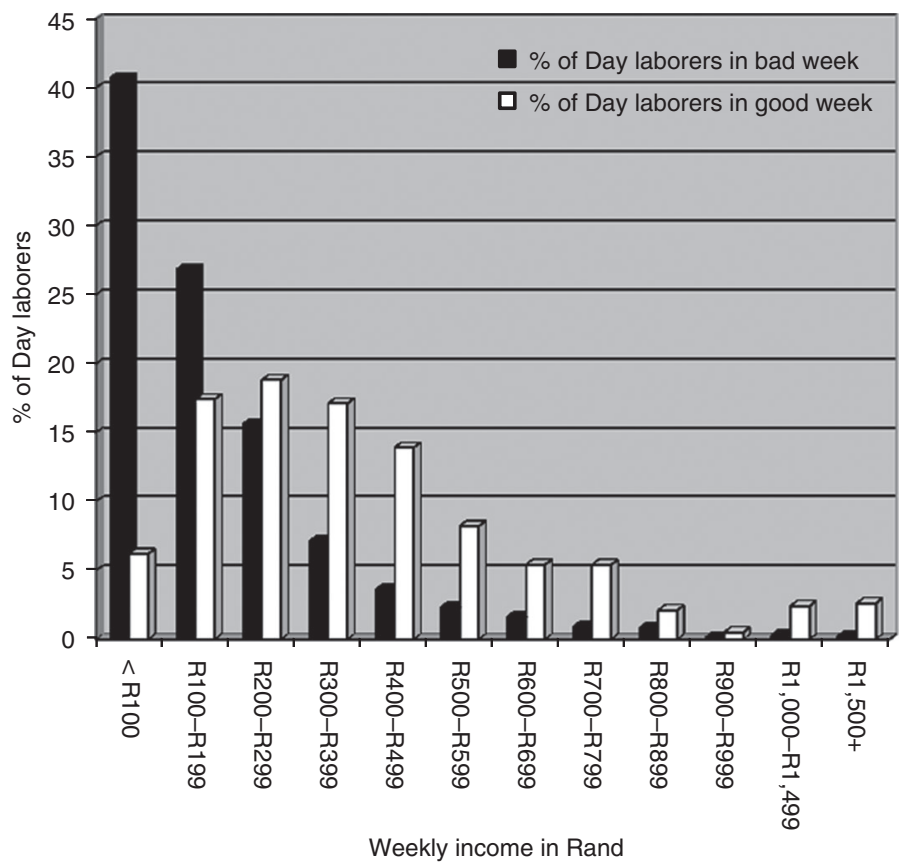

Source: Survey data

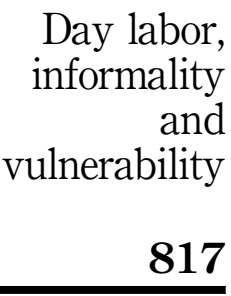

Figure 6.

Earnings of day laborers in South Africa in a good week vs a bad week

perhaps with the exception of the highest wages earned by the most educated workers (Figure 7). Notable inthese statistics is the relative parity in daily wages among workers during "bad" days, a further indication that workers with differing levels of educational attainment compete directly with one another.

In addition to their low wages and irregular employment, day laborers in the USA and South Africa experience numerous hardships in their search for work. In the USA, day laborers routinely suffer violations of basic labor standards, especially wage theft by employers. Valenzuela et al. (2006) found that 49 percent of day laborers suffered at

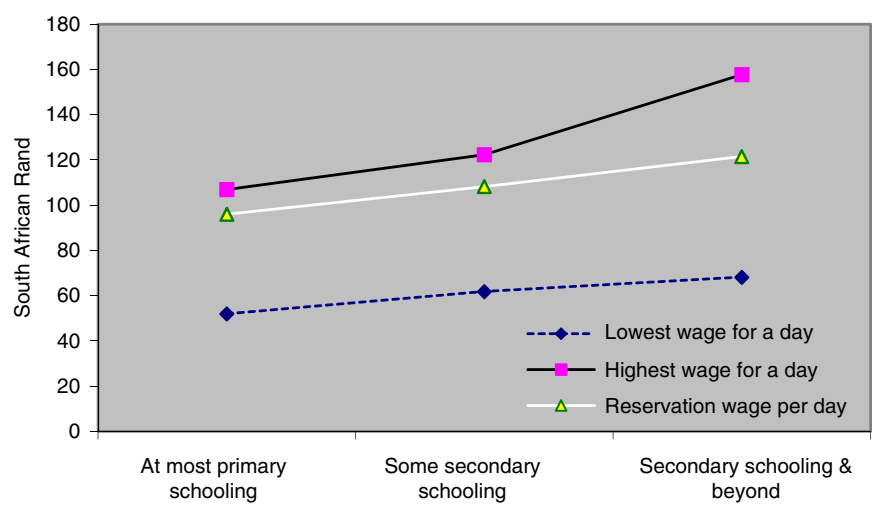

Figure 7.

Mean values of daily income measures across categories of educational attainment for day laborers, South Africa

Source: Survey data 
IJM

36,6

818

least one instance of the nonpayment of wages in a two-month period, while a similar proportion reported instances of being underpaid during the same period. The high incidence of labor law violations is directly related to the economic vulnerability of this workforce. Unscrupulous employers frequently exploit day laborers' need for work, abandoning workers at worksites and failing to pay them for their work. In addition, employers often threaten to report workers to federal immigration authorities, and engage in other forms of retaliation, if workers speak out against substandard conditions and violations of labor laws (Fussell, 2011; Mehta and Theodore, 2006). In South Africa, there is little evidence to suggest that day laborers experience such widespread violations of labor laws. Here, however, because the work is so poorly paid and infrequent, day laborers suffer high levels of homelessness, hunger, and other forms of material deprivation.

One strategy for raising wages is to work repeatedly for the same employer. Frequent employment not only stabilizes employment and earnings, it also allows day laborers to demonstrate attributes, such as skill and dependability, which are desired by employers. Employers may be willing to pay a wage premium to workers who demonstrate these attributes. Bartley and Roberts (2006), for example, found a positive and statistically significant relationship between repeat employment and real wages among workers employed through day-labor temporary staffing agencies in the USA, even when controlling for organizational form and human capital. Repeat employment is common in USA day-labor markets, where 69 percent of day laborers report that they were rehired by the same employer, suggesting a pattern of satisfied employers and willing workers. In South Africa, Blaauw (2010) found that day laborers who were rehired by an employer earned, on average, approximately 30 percent more than those who were not. This positive and statistically significant relationship suggests that Bartley and Roberts' findings may hold for workers in emerging economies as well. However, in South Africa, less than 15 percent of the day laborers surveyed reported that they had been repeatedly hired by the same employer, thereby limiting the positive wage effects that might accrue to workers through the practice of day laborer rehiring.

\section{Interventions aimed at the inclusion of day laborers}

Hypercompetitive conditions in day-labor markets militate against individualized attempts to raise wages and improve working conditions. If a given worker balks at a wage offer or refuses to undertake hazardous job assignments, employers have enormous leeway in replacing the worker since the employment agreement is nonbinding and the supply of job seekers is seemingly endless. Therefore, in a market characterized by vast labor supply-demand imbalances, combined with an absence of effective state enforcement of labor standards, collective strategies are required in order to raise the floor on wages and conditions. Collective action, in turn, requires organizing, bolstered by a resolve among the workforce to attempt to regulate the labor market from within. In the USA, day laborers have exhibited the ability to do just this, by developing an internal decision-making structure at informal hiring sites that allows them to set and maintain minimum-wage rates, shun abusive employers, and defend hiring sites in the face of efforts by some municipal governments and local law-enforcement authorities to ban the activity. In their more developed and institutionalized form, these strategies have led to the creation of worker centers, a set of labor market intermediaries situated at the heart of the informal economy.

An increasing number of worker centers (Fine, 2006; Gordon, 2005) and other non-profit organizations in the USA seek to intervene and set standards in the informal 
economy, while also aiding workers in managing the multifarious hardships associated with working in the informal economy (Gleeson, 2012; Martin, 2010). Day labor worker centers typically establish hiring halls from which day-labor markets can be better regulated. As a direct intervention in informal labor markets, these worker centers set wage rates, develop job-allocation systems, and assist day laborers in redressing wage theft (Theodore et al., 2009; Theodore, 2015). In addition, some are actively engaged in providing workplace safety training. Evaluation research has found that these interventions are effective in raising wages and improving health and safety on the job (Meléndez et al., 2013, 2014).

In the USA, day laborer organizing has occurred primarily under the auspices of the National Day Laborer Organizing Network (NDLON), and its 43 member organizations. Founded in 2000, NDLON is an alliance of independent worker centers that operate worker-led organizations designed to promote collective action among day laborers. NDLON-affiliated worker centers do more than establish and monitor rules in day-labor markets. They represent an exercise in direct democracy in a sector of the economy that lacks transparency and which confers its benefits so inequitably. By developing workforce strategies to intervene in these markets, day labor worker centers reinforce the notion that, through collective action, workers can be a regulatory force in the informal economy. Initiatives of this nature hold the potential of enabling day laborers to mitigate the risks they face in the informal economy and, if successful, establish more sustainable labor standards in the day-labor market.

Within South Africa, interventions in day-labor markets have been coordinated by Men on the Side of the Road (MSR), a social-enterprise organization founded in Cape Town in 1999 but with affiliates in other parts of the country. Like worker centers, MSR affiliates replace the informality of street-corner hiring sites with systems to safeguard workers' wages and working conditions. In addition, MSR has sought to increase the skills of day laborers through job training, and to develop ways for helping employers evaluate worker skills. The need for skills certification in the informal economy has been recognized in the literature (Mehrotra and Biggeri, 2007). This research has shown that there is some willingness on the part of employers to reward the skills of day laborers with higher pay, and that some employers are even willing to pay an efficiency wage to keep skilled workers in their employ. Day laborers registered at MSR offices are evaluated by industry insiders who can validate worker skills in several construction-related occupations. Once certified, the skill in question can be listed on the back of the worker's identification card, thus enabling prospective employers to improve their screening processes and hire skilled day laborers who are qualified for the job. On the supply side of the job market, the increased legibility of worker skills may increase the negotiating power of more skilled day laborers while also improving the functioning of the labor market.

\section{Conclusions}

This paper has compared the labor market experiences of day laborers in the USA and South Africa, their location within restructuring labor markets, and the vulnerabilities they face in the informal economy. The comparison of day labor work in the two countries has identified a number of similarities between informal-sector workers in a developed and developing economy. Operating beyond the reach of government regulation of labor standards, and in the context of sizable labor surpluses, the fierce competition for jobs that occurs at informal hiring sites places downward pressures on

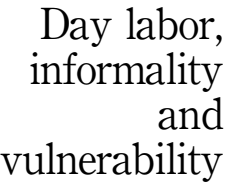

819 
IJM

36,6

820

wages and working conditions. Low pay and intermittent work is the norm, and the overwhelming majority of day laborers must contend with the vicissitudes of a labor market that is in a constant state of flux.

The day-labor markets of the two countries perform somewhat different functions within regional economies. In both countries, there are close links between day-labor markets and the residential construction and landscaping industries, and day laborers help employers meet their demand for temporary workers hired on an as-needed basis. The burdens associated with the instability of labor demand, however, are primarily borne on the supply side of this employment relationship: day labor work is poorly paid and highly contingent. Although there appears to be greater upward mobility of day laborers in the USA than in South Africa, the extent to which workers are able to permanently move out of this segment of the informal economy should not be exaggerated. A sizable share of workers are employed as day laborers for extended periods of time, and it is likely that many of those who enter more formalized jobs retain little more than a tenuous hold on these positions. For many, a return to day labor can be expected.

Within South Africa, day labor can be regarded as a survival strategy. The growth of day labor in South Africa over the past decade is a manifestation of a formal labor market that is incapable of clearing the supply of labor, as postulated by orthodox labor market theory. Here, day-labor markets are catchment zones for the structurally unemployed, and labor surpluses and below-poverty level wages are the norm. Furthermore, there are signs that increasing competition among day laborers is straining relations between foreign-born and South African-born day laborers (Blaauw et al., 2012), an additional challenge that must be overcome for there to be broad-based collective action to safeguard labor standards. As the employment of last resort, day labor may allow workers to subsist on the fringes of the mainstream economy, but it also may ultimately lead to their further isolation from jobs in the formal sector. There appears to be little upward mobility for day laborers in South Africa, and given the economy's persistently high unemployment rate, the prospects for transitions into more stable employment are indeed dim. Meanwhile, the capacity of informal hiring sites to absorb greater numbers of underemployed workers - and to compensate for the inadequacies of the mainstream labor market - is quite limited. Absent a substantial increase in economic activity organized through day-labor markets, day-labor income must be shared among an ever-growing workforce, leading to a diminishing level of real earnings for a given worker. For this reason, it would be unsurprising if reservation wages were to decline over time across this segment of the informal economy.

The conditions that have lead to the growth of day labor in the USA and South Africa are such that it is improbable that wages and working conditions will improve without the determined efforts of workers themselves to collectively bargain their terms of employment. This includes collectively setting wages and monitoring conditions on the job. Evidence from the USA indicates that such collective strategies are in fact possible and effective, even in hypercompetitive day-labor markets, while throughout Africa there are signs that workers in a range of informalized sectors are organizing to safeguard their livelihoods (Lindell, 2010). As long as governments continue to lack the will, and perhaps also the means, to adequately enforce labor standards in informalizing sectors, worker organizing will likely be the principal regulatory strategy to improve conditions in these fast-growing zones of restructuring economies. 


\section{References}

Banerjee, A., Galiani, S., Levinsohn, J., Mclaren, Z. and Woolard, I. (2007), "Why has unemployment risen in the New South Africa?", Working Paper No. 13167, National Bureau of Economic Research, Cambridge, MA.

Barker, F. (2007), The South African Labour Market, 5th ed., Van Schaik, Pretoria.

Barrar, E.M. (2010), "Township youth perceptions of poverty and unemployment in Cape Town, South Africa", unpublished minor-dissertation, Master of Philosophy in Development Studies, University of Cape Town, Cape Town.

Bartley, T. and Roberts, W.T. (2006), "Relational exploitation: the informal organization of day labor agencies", WorkingUSA: The Journal of Labor and Society, Vol. 9 No. 1, pp. 41-58.

Bhorat, H. (2004), "Labour market challenges in the post-apartheid South Africa", South African Journal of Economics, Vol. 72 No. 5, pp. 940-977.

Bhorat, H., Leibbrandt, M., Maziya, M., van der Berg, S. and Woolard, I. (2001), Fighting Poverty Labour Markets and Inequality in South Africa, UCT Press, Cape Town.

Blaauw, P.F. (2010), "The socio-economic aspects of day labouring in South Africa”, unpublished doctoral thesis, Department of Economics \& Econometrics, University of Johannesburg, Johannesburg.

Blaauw, P.F., Louw, H. and Schenck, R. (2006), "The employment history of day labourers in South Africa and the income they earn - a case study of day labourers in Pretoria", South African Journal of Economic and Management Sciences, Vol. 9 No. 4, pp. 458-471.

Blaauw, P.F., Pretorius, A.M., Schoeman, C.H. and Schenck, C.J. (2012), "Explaining migrant wages: the case of Zimbabwean day labourers in South Africa", International Business \& Economics Research Journal, Vol. 11 No. 12, pp. 1333-1346.

Centre for Development and Enterprise (2012), Routes into Formal Employment: Public and Private Assistance to Young Job Seekers, Centre for Development and Enterprise, Johannesburg.

Doussard, M. (2013), Degraded Work: The Struggle at the Bottom of the Labor Market, University of Minnesota Press, Minneapolis, MN.

Erlich, M. and Grabelsky, J. (2006), "Standing at a crossroads: the building trades in the twentyfirst century", Labor History, Vol. 46 No. 4, pp. 421-445.

Fine, J. (2006), Worker Centers: Organizing Communities at the Edge of the Dream, Cornell University Press, Ithaca, NY.

Fussell, E. (2011), "The deportation threat dynamic and victimization of Latino migrants: wage theft and robbery", The Sociological Quarterly, Vol. 52 No. 4, pp. 593-615.

Gentsch, K. and Massey, D.S. (2011), "Labor market outcomes for legal Mexican immigrants under the new regime of immigration enforcement”, Social Science Quarterly, Vol. 92 No. 3, pp. 875-893.

Gleeson, S. (2012), Conflicting Commitments: The Politics of Enforcing Immigrant Worker Rights in San Jose and Houston, Cornell University Press, Ithaca, NY.

Gordon, J. (2005), Suburban Sweatshops: The Fight for Immigrant Rights, Harvard University Press, Cambridge, MA.

Hudson, K. (2007), "The new labor market segmentation: labor market dualism in the new economy", Social Science Research, Vol. 36 No. 1, pp. 286-312.

Iskander, N. and Lowe, N. (2010), "Hidden talent: tacit skill formation and labor market incorporation of Latino immigrants in the United States", Journal of Planning Education and Research, Vol. 30 No. 2, pp. 132-146.
Day labor, informality and vulnerability 
IJM

36,6

822

Iskander, N. and Lowe, N. (2013), "Building job quality from the inside-out: Mexican immigrants, skills, and jobs in the construction industry", Industrial and Labor Relations Review, Vol. 66 No. 4, pp. 785-807.

Lindell, I. (Ed.) (2010), Africa's Informal Workers: Collective Agency, Alliances, and Transnational Organizing in Urban Africa, Zed Books, London.

Loots, A.E. (1998), "Job creation and economic growth", The South African Journal of Economics, Vol. 66 No. 3, pp. 319-336.

McConnell, C.R., Brue, S.L. and Macpherson, D.A. (2009), Contemporary Labor Economics, 8th ed., McGraw-Hill, New York, NY.

McKeever, M. (2007), "Fall back or spring forward? Labor market transitions and the informal economy in South Africa", Research in Social Stratification and Mobility, Vol. 24, pp. 73-87.

Martin, N. (2010), "The crisis of social reproduction among migrant workers: interrogating the role of migrant civil society", Antipode, Vol. 42 No 1, pp. 127-151.

Mehrotra, S. and Biggeri, M. (Eds) (2007), "The empirical context and a theoretical framework", Asian Informal Workers, Global Risks, Local Development, Routledge, London, pp. 3-31.

Mehta, C. and Theodore, N. (2006), "Workplace safety in Atlanta's construction industry: institutional failure in temporary staffing arrangements", Working USA: The Journal of Labor and Society, Vol. 9 No. 1, pp. 59-77.

Meléndez, E.J., Visser, M.A., Valenzuela, A. Jr and Theodore, N. (2013), "Day labourers' workrelated injuries: an assessment of risks, choices, and policies", International Migration Early View.

Meléndez, E.J., Visser, M.A., Theodore, N. and Valenzuela, A. Jr (2014), "Worker centers and day laborers' wages”, Social Science Quarterly, Vol. 95 No. 4, pp. 835-851.

Muller, C. (2003), "Investigating South Africa's informal sector: measurement, participation, and earnings", unpublished masters-thesis, Department of Economics, University of Natal, Durban.

Peck, J. (1996), Work-place: The Social Regulation of Labor Markets, Guilford, New York, NY.

Peck, J. and Theodore, N. (2012), "Politicizing contingent labor: countering neoliberal labormarket regulation [...] from the bottom up?", South Atlantic Quarterly, Vol. 111 No. 4 No 1, pp. 741-761.

Quantec (2007), Employment Time Series Data: Circumventing the Statistical Shortcomings, Quantec, Pretoria.

Saunders, S.G. (2005), "Estimates of the informal economy in South Africa: some macroeconomic policy implications", unpublished doctoral thesis, Department of Economics, University of Johannesburg, Johannesburg.

Schenck, C.J. and Blaauw, P.F. (2008), "Day labourers in Pretoria, Windhoek and the United States - a comparison of two capitals and a different world", Acta Commercii, Vol. 8 No. 1, pp. 90-102.

Schoeman, C.H. and Blaauw, P.F. (2009), "Unemployment in South Africa 1970-2002: the development of a configuration concern for future employment", Journal of Economic and Financial Sciences, Vol. 3 No. 1, pp. 87-98.

Schoeman, C.H., Botha, I. and Blaauw, P.F. (2010), "Labour conflict and the persistence of underemployment in South Africa", South African Journal of Economic and Management Sciences, Vol. 13 No. 3, pp. 272-292.

Theodore, N. (2015), "Rebuilding the house of labor: unions and worker centers in the residential construction industry", Working USA: The Journal of Labor and Society, Vol. 18 No. 1, pp. 59-76. 
Theodore, N., Valenzuela, A. and Meléndez, E. (2006), "La esquina (the corner): day laborers on the margins of New York's formal economy”, Working USA: The Journal of Labor and Society, Vol. 9 No. 4, pp. 407-423.

Theodore, N., Valenzuela, A. Jr and Meléndez, E. (2009), "Worker centers: defending labor standards for migrant workers in the informal economy", International Journal of Manpower, Vol. 30 No. 5, pp. 422-436.

Vakalisa, N.C.G. (2005), "Unemployment in South Africa on the rise: are the schools and universities to blame?", Africa Education Review, Vol. 2 No. 1, pp. 40-58.

Day labor, informality and

vulnerability

823

Valenzuela, A. Jr, Theodore, N., Meléndez, E. and Gonzalez, A.L. (2006), On the Corner: Day Labor in the United States, University of California, Los Angeles, CA.

Williams, C.C. (2010), "The changing conceptualisation of informal work in developed economies", in Marcelli, E., Williams, C.C. and Joassart, P. (Eds), Informal Work in Developed Nations, Routledge, London, pp. 11-33.

\section{Corresponding author}

Professor Nik Theodore can be contacted at: theodore@uic.edu

For instructions on how to order reprints of this article, please visit our website: 